UCRL-ID-127458

\title{
TRU Waste from the Superblock
}

\author{
Thomas T. Coburn
}

May 27, 1997

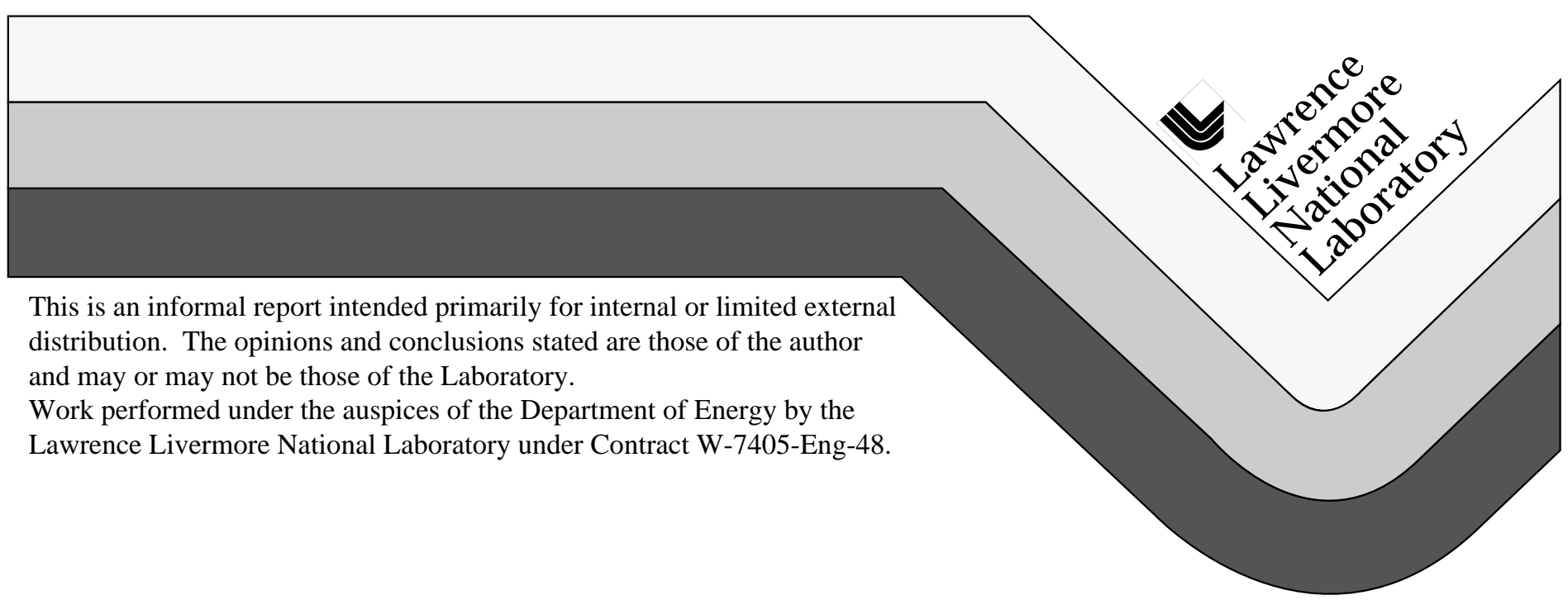




\section{DISCLAIMER}

This document was prepared as an account of work sponsored by an agency of the United States Government. Neither the United States Government nor the University of California nor any of their employees, makes any warranty, express or implied, or assumes any legal liability or responsibility for the accuracy, completeness, or usefulness of any information, apparatus, product, or process disclosed, or represents that its use would not infringe privately owned rights. Reference herein to any specific commercial product, process, or service by trade name, trademark, manufacturer, or otherwise, does not necessarily constitute or imply its endorsement, recommendation, or favoring by the United States Government or the University of California. The views and opinions of authors expressed herein do not necessarily state or reflect those of the United States Government or the University of California, and shall not be used for advertising or product endorsement purposes.

This report has been reproduced directly from the best available copy.

Available to DOE and DOE contractors from the

Office of Scientific and Technical Information

P.O. Box 62, Oak Ridge, TN 37831

Prices available from (615) 576-8401, FTS 626-8401

Available to the public from the

National Technical Information Service

U.S. Department of Commerce

5285 Port Royal Rd.,

Springfield, VA 22161 


\section{TRU Waste from the Superblock}

\section{Premise}

This data analysis is to show that weapons grade plutonium is of uniform composition to the standards set by the Waste-Isolation Pilot Plant (WIPP) Transuranic Waste Characterization Quality Assurance Program Plan (TRUW Characterization QAPP, Rev. 2, DOE, Carlsbad Area Office, November 15, 1996).

\section{Introduction}

The major portion of Superblock transuranic (TRU) waste is glove-box trash contaminated with weapons grade plutonium. This waste originates in the Building 332 (B332) radioactive-materials area (RMA). Because each plutonium batch brought into the B332 RMA is well characterized with regard to nature and quantity of transuranic nuclides present, waste also will be well characterized without further analytical work, provided the batches are quite similar. A sample data set was created by examining the 41 incoming samples analyzed by Ken Raschke (using a $\gamma$-ray spectrometer) for isotopic distribution and by Ted Midtaune (using a calorimeter) for mass of radionuclides. The 41 samples were from separate batches analyzed May 1993 through January 1997. All available weapons grade plutonium data in Midtaune's files were used. Alloys having greater than $50 \%$ transuranic material were included. The intention of this study is to use this sample data set to judge "similarity."

The database represents a random, but incomplete, set of the weapons grade plutonium sample population in the Superblock. It includes 91\% of the material received in 1996 and approximately $60 \%$ of the 1995 material. The proportion of material from earlier years is unspecified, but is certainly greater than $50 \%$. The data set is in excess of the $5 \%$ of total needed for a sound statistical treatment. It should be sufficient to answer the following questions:

- Does the average isotopic composition match that assumed by Hazardous Waste Management (HWM) Division for weapons grade plutonium?

- Do sample isotopic fractions disperse as narrow frequency distributions that justify use of an average isotopic composition?

- How much of the sample variation results from composition difference and how much from analytical uncertainty?

- Can compliance goals—expressed in terms of $\alpha$-activity — be met with only a partial analysis of the radionuclides in the waste?

- Does the batch (date of manufacture) of plutonium have a significant effect on a waste's radioactive properties, or are other factors of greater importance?

- When alloyed with nontransuranic metals, does weapons grade plutonium have the same isotopic composition by $\gamma$-ray spectrometer analysis? 
A segmented gamma scanner (SGS) will be used to analyze TRU waste drums. The SGS procedure differs from the more accurate analytical spectrometer method used to obtain the data here. Calorimetry is not available to the SGS for the determination of radionuclide mass. Error in the SGS procedure is dominated by difficulties in matching the sample matrix of calibration standards to that of heterogeneous waste having considerable drum-to-drum variability. The resulting systematic bias in the mass measurement (mass of a plutonium isotope-generally the major one, $\mathrm{Pu}$-239—-that produces a given gamma ray emission intensity) limits analysis accuracy. In light of the uncertainties in mass measurement, the data analysis that follows shows that weapons grade plutonium has a sufficiently consistent composition that analyzing for all the radionuclides known or suspected to be present does not improve the accuracy of alpha activity. Thus, one isotope can be measured and average ratios applied. As a result, one can avoid analyzing waste drums for the total set of radionuclides when generator knowledge attests to weapons grade plutonium as the only TRU material present. Furthermore, this data analysis provides a documentation of generator knowledge that the WIPP QAPP, Section 4, demands.

\section{Sample Population, Averages, and Standard Deviations}

Appendix I contains the complete data set. Plutonium isotope weights sum to 1 for each analyzed sample. Other radionuclides are given as weight fractions relative to plutonium $(\mathrm{Pu})$ summing to 1. Figure 1a shows the complete distribution of $\mathrm{Pu}-239$ values. Figure $1 \mathrm{~b}$ is a blowup of the range of interest-the range near the average. The two figures differ in the cuts taken (Figure 1a slices started at 0.9310 \pm 0.0004 ; Figure 1b, at $0.9350 \pm 0.0003$ ), so they look a bit different. Nevertheless, there is a nearly Gaussian frequency distribution-about as Gaussian as expected for a sample set of this sizeprovided a single outlier is excluded. The outlier proves to be a purified $\mathrm{Pu}-239$ sample (Pu-239 as a fraction of total Pu: 0.9771, rather than 0.9385) and may not, in fact, be correctly called "weapons grade." A statistical test, assuming a normal population distribution, indicates that the chance this batch belongs to the set of weapons grade samples, as defined by the rest of the group, is less than 1 in $10^{200}$.

Averages, with and without outlier, along with standard deviations were calculated and are shown in Table 1. Weighted averages are also given. The mass of plutonium in each batch was used as the weighting factor. Rejecting the outlier changes the average and improves the standard deviation, but weighted and unweighted averages are essentially the same. Note that, while the raw data required plutonium isotopes to sum to 1 (see the Appendix I summary for averages in this format), the total of radionuclides is made to equal 1 in Table 1 and henceforth. 
Table 1. Data Averages from Midtaune's Sample Population (as weight fraction of total radionuclides)

\begin{tabular}{|c|c|c|c|c|c|c|c|c|c|c|c|c|}
\hline \multirow[b]{2}{*}{$\begin{array}{l}\text { Radio- } \\
\text { nuclide }\end{array}$} & \multicolumn{3}{|c|}{$\begin{array}{c}\text { Unweighted } \\
\text { (Outlier [\#17] Omitted) }\end{array}$} & \multirow{2}{*}{$\begin{array}{c}\text { Weighted } \\
\text { by Mass of } \\
\text { Pu } \\
\text { Average } \\
\text { (Weighted) }\end{array}$} & \multirow[b]{2}{*}{ HWM Data } & \multirow[b]{2}{*}{$\begin{array}{c}\text { PDP } \\
\text { Validation } \\
\text { Standard }\end{array}$} & \multirow[b]{2}{*}{$\begin{array}{c}\text { Analytical } \\
\text { Validation } \\
\text { Standard }\end{array}$} & \multirow[b]{2}{*}{$\begin{array}{l}\text { Calculated } \\
\text { from Eq (1) }\end{array}$} & \multicolumn{3}{|c|}{$\begin{array}{c}\text { Unweighted } \\
\text { (All Midtaune's Data) }\end{array}$} & \multirow{2}{*}{$\begin{array}{l}\text { Weighted } \\
\text { by Mass } \\
\text { of Pu } \\
\text { Average } \\
\text { (Weighted) }\end{array}$} \\
\hline & Average & $\begin{array}{l}\text { Std. } \\
\text { Dev. }\end{array}$ & (Rel.) & & & & & & Average & $\begin{array}{l}\text { Std. } \\
\text { Dev. }\end{array}$ & (Rel.) & \\
\hline Pu-238 & 0.000124 & 0.000028 & (22.7\%) & 0.000127 & 0.000160 & 0.000145 & 0.000094 & & 0.000122 & 0.000032 & $(26.5 \%)$ & 0.000124 \\
\hline Pu-239 & 0.936471 & 0.001157 & $(0.12 \%)$ & 0.936486 & 0.934640 & 0.936797 & 0.937337 & 0.915639 & 0.937442 & 0.006142 & $(0.66 \%)$ & 0.937589 \\
\hline Pu-240 & 0.059293 & 0.001137 & $(1.92 \%)$ & 0.059199 & 0.059000 & 0.059393 & 0.05852 & 0.061339 & 0.058401 & 0.005831 & $(10.0 \%)$ & 0.058191 \\
\hline Pu-241 & 0.001792 & 0.000448 & $(25.0 \%)$ & 0.001767 & 0.003810 & 0.002235 & 0.002335 & 0.004094 & 0.001752 & 0.000511 & $(29.2 \%)$ & 0.001722 \\
\hline Pu-242 & 0.000277 & 0.000076 & (27.4\%) & 0.000266 & 0.000400 & 0.000559 & 0.000291 & 0.000274 & 0.000271 & 0.000085 & (31.4\%) & 0.000259 \\
\hline Am-241 & 0.001946 & 0.001300 & $(66.8 \%)$ & 0.002052 & 0.002020 & 0.000872 & 0.001427 & & 0.001916 & 0.001298 & $(67.7 \%)$ & 0.002016 \\
\hline $\mathrm{Np}-237$ & 0.000097 & 0.000065 & (67.1\%) & 0.000103 & & & & & 0.000097 & 0.000065 & $(67.1 \%)$ & 0.000103 \\
\hline
\end{tabular}


For data with outlier excluded, the major radionuclide, $\mathrm{Pu}-239$, has a very narrow relative standard deviation $(1 \sigma=0.12 \%)$. Small scatter is consistent with a narrow Gaussian distribution (see Figure 1). The Pu-240 relative standard deviation is $1.92 \%$. The absolute standard deviations of Pu-240 and $\mathrm{Pu}-239$ are comparable, however. Two other well-characterized weapons grade $\mathrm{Pu}$ samples are included for comparison. They are standard samples for validation of the gamma spectrometer (Calorimetry Exchange Reference Sample, from 1982) and the high-sensitivity neutron instrument (PDP Working Reference Material, LANL, 7/15/95). They fit into the data set nicely. Also, batches of both "pure" weapons grade $\mathrm{Pu}$ and weapons grade $\mathrm{Pu}$ alloyed with nontransuranic metals were included. The fraction of each radionuclide in the set of "pure" samples matched that in the smaller set of 12 alloy batches to well within the $1 \sigma$ standard deviation. For $\mathrm{Pu}-239$, for example, its average radionuclide fraction in "pure" material was $0.93663 \pm 0.00106$; and, in alloys, it was $0.93612 \pm 0.00134$.

\section{Composition Variation versus Analysis Precision}

The observed scatter may result from analytical imprecision, from real differences in the composition of weapons grade $\mathrm{Pu}$, or from both. Table 2 shows data scatter as compared to the claimed analysis error and to experimental precision. Data scatter is expressed as one standard deviation for that set of samples with outlier omitted. Analysis error includes the gamma spectrometer counting error-essentially, the observed emission curve (gamma rays detected per unit time versus energy) as compared to the theoretical - and inaccuracy in the total radionuclide weight as determined by calorimetry. In this case, the sample set was only the 27 most recent analyses. Prior to October 1994, analytical results came without error bars. The precision estimate comes from 64 analyses of two weapons grade $\mathrm{Pu}$ validation standards that were run in 1996. The procedure tests the gamma spectrometer $(\gamma S)$ but does not speak to matrix effects, sampling errors, or errors associated with calorimetry. 
Table 2. Analysis Error and Precision Relative to Data Scatter

\begin{tabular}{cccccc}
\hline & \multicolumn{2}{c}{ Data Set (Outlier Omitted) } & \multicolumn{2}{c}{ Analysis Error (1 $\sigma)$} & $\gamma$ S Precision \\
Radionuclide & Rel. Std. Dev. & Extreme Dev. & Average & Extreme & (1996, Rel.) \\
\hline \hline Pu-238 & $22.72 \%$ & $58.51 \%$ & $2.93 \%$ & $5.33 \%$ & $3.33 \%$ \\
Pu-239 & $0.12 \%$ & $0.32 \%$ & $0.33 \%$ & $0.58 \%$ & $0.03 \%$ \\
Pu-240 & $1.92 \%$ & $5.32 \%$ & $0.61 \%$ & $0.88 \%$ & $0.42 \%$ \\
Pu-241 & $24.99 \%$ & $57.03 \%$ & $0.56 \%$ & $0.80 \%$ & $0.35 \%$ \\
Pu-242 & $27.41 \%$ & $73.08 \%$ & $10.00 \%$ & & \\
Am-241 & $66.80 \%$ & $124.75 \%$ & $0.61 \%$ & $1.06 \%$ & $0.29 \%$ \\
Np-237 & $69.72 \%$ & $353.93 \%$ & & & \\
\hline
\end{tabular}


The conservative error assessment in Table 2 suggests that variables inherent in the analytical data are comparable with sample variation for the major isotope, $\mathrm{Pu}$-239. Scatter due to a variation in composition is evident for minor components. At trace levels, signal-to-noise (detection limit) and interferences from major component emissions (tailing and perhaps secondorder emission peaks) make determination of an analysis error difficult. No $\mathrm{Np}$-237 precision/accuracy is estimated; the Pu-242 error bar is said to be $\pm 10 \%$ by default. Analysis of minor components-in particular, Am-241-may have some worth, but an average weapons grade $\mathrm{Pu}$ composition can be assumed with confidence.

With regard to sample variability, relative standard deviation increases as the isotopic fraction decreases for $\mathrm{Pu}-239, \mathrm{Pu}-240$, and $\mathrm{Pu}-242 / \mathrm{Pu}-238$. Batch age at the time of analysis makes an important contribution to scatter for Pu-241. With a relatively short half life of 14.2 years, $\mathrm{Pu}-241$ content gradually decreases. Batches were analyzed on receipt, and no direct specification of age was provided (i.e., analysis date and sample age are unrelated). There should be a corresponding increase in the daughters (Am-241 and Np-237) as Pu-241 decays. Np-237 content is too close to the detection limit to give the good negative correlation with $\mathrm{Pu}-241$ content that might be expected of a daughter (see Figure 2a). Surprisingly, the negative correlation of Am-241 with Pu-241 is even poorer (see Figure $2 b$ ). In fact, this daughter shows substantially more scatter than expected. A chemical as well as physical aspect to the purification process exists for extraneous nuclide impurities that the preparation process leaves in weapons grade $\mathrm{Pu}$ ( e.g., americium and neptunium). This adds another variable and further increases the standard deviation. Thus, the chemistry aspects of the separation process must dominate in the case of Am241. Americium content is small, but quite scattered, most likely reflecting the varying extent of chemical removal.

\section{Correlations that Fix Nuclide Content}

For a purely physical purification process, the amount of a residual impurity can be proportional to how closely its physical characteristic matches that of the desired material. In the rare case where secondary effects are inconsequential and no large concentration differences exist, one expects a normal distribution around the desired property-provided a good quantitative measure of the physical property is available. Because normal distributions are exponential in each direction, any impurity's concentration should drop away exponentially as its property becomes less like the material in question. Mass is the key physical property for separation of Pu-239. As Figure 3a shows, those long-lived $\mathrm{Pu}$ isotopes (with mass greater than 239 amu) plot linearly with mass on an exponential scale. Data from all samples analyzed since June 1996, are included in the Figure 3a plot, along with the average line (the unweighted 40 -sample average with outlier omitted). If $\mathrm{x}$ is 
isotopic mass and $[\mathrm{Pu}-\mathrm{x}]$ is concentration of a plutonium isotope of mass $\mathrm{x}$ expressed as weight fraction of plutonium, the following expression applies:

$$
[\mathrm{Pu}-\mathrm{x}]=\mathrm{A}^{*} \mathrm{e}^{\mathrm{B}^{* x}}
$$

Corresponding semi-log plots of average data and of the outlier data are also shown (see Figure $3 \mathrm{~b}$ ). Isotopic fractions as calculated from the average plot are included in Table 1 (see "Calculated from Eq. (1)"). Because only three points (Pu-239, $\mathrm{Pu}-240$, and $\mathrm{Pu}-242)$ can be used to obtain the best fit line, the rather large scatter associated with the $\mathrm{Pu}-242$ data limits the practical use of this curve. However, expression (1) provides a means of testing raw data quality. Any line having a very different slope or intercept cannot have resulted from analysis of only weapons grade $\mathrm{Pu}$. Another grade of $\mathrm{Pu}$ or weapons grade material contaminated with a Pu isotope or isotope mixture will not lie on the Figure 3a-b curve. Outlier data provide an example.

Plutonium isotopic fractions from the $\gamma$-ray spectrometer by decree sum to 1 . If isotopic impurities in Pu-239 decrease rapidly with mass, as they do, then expressions such as the following should be good approximations:

$$
\begin{gathered}
{[\mathrm{Pu}-240]=\mathrm{A}^{\prime}+(1-[\mathrm{Pu}-239])} \\
{[\mathrm{Pu}-241]=\mathrm{A}^{\prime \prime}+(1-[\mathrm{Pu}-240]-[\mathrm{Pu}-239])}
\end{gathered}
$$

Figure 4 shows plots of these expressions for all raw data including the outlier. An excellent fit results. The constant defined by a best-fit line is given on each plot. Expressions (2) and (3) can serve as limited tests of the SGS or gamma spectrometer's output. They provide a calibration check and an alternative means of determining $\mathrm{Pu}-241$. Because $\mathrm{Pu}$ isotopic fractions are forced to equal 1, such expressions are not totally independent of the good data averages of Table 1; yet they are an additional method of judging the uniform consistency of the sample set. A single point might be expected if compositional variation and analytical error were absent. Expression (3) and Figure $4 \mathrm{~b}$ indicate some sample variability. However, the artificial constraint that $\mathrm{Pu}$ isotopes must sum to 1 skews the data and obviates a defensible conclusion with regard to compositional variation versus analytical error as the source of scatter.

\section{Meeting disposal requirements}

The WIPP QAPP, Rev. 2, asks for measurement of waste radionuclide contents with precision and accuracy demands specified in terms of $\alpha$-activity. Total alpha-activity is stated in alpha curies per gram of the weapons grade $\mathrm{Pu}$ sample and defined as follows:

$$
\alpha-A c t=a[P u-238]+b[P u-239]+c[P u-240]+d[P u-241]+e[P u-242]+f[A m-
$$

where, a through $f$ are specific $\alpha$-activities of each nuclide. 
The QAPP allows omission of those nuclides with half lives less than 20 years, specifically $\mathrm{Pu}-241$, from the calculation, if desired. Given the large proportion of $\mathrm{Pu}-239$ in weapons grade material, this particular radionuclide dominates the calculation of total $\alpha$-activity per gram. Pu-239 content is, however, purposely the most accurately measured value. Appendix II provides input data, physical constants, and an example calculation of $\alpha$-activity per gram sample. In general, determination of $\alpha$-activity and related properties such as $\mathrm{Pu}-239$ fissile gram equivalents, effective power, and thermal power are very precise and accurate. The analytical laboratory's $\gamma$-ray spectrometer validation sample serves as an "effective power" standard (certified as $2.450 \mathrm{~mW} / \mathrm{g} \pm 0.05 \%$ ); multiple in-house analyses during 1996 gave $2.444 \mathrm{~mW} / \mathrm{g} \pm 0.08 \%$.

Table 3 shows $\alpha$-activities calculated from the sample data set. The $\alpha$-activity of weapons grade plutonium having the composition historically assumed by HWM for this material is $0.0812 \alpha \mathrm{Ci} / \mathrm{g}$ (see Table 1, and note that this composition was assumed for the Appendix II calculations). It is, in fact, difficult to argue that the HWM-assumed composition is identical to the average calculated here; isotopic fractions are near the extreme for several minor radionuclides (see Table 1). Nevertheless, the assumed composition is satisfactory, given that $\alpha$-activity agrees to within $1 \%$. Furthermore, $\alpha$-activity per gram of sample calculated from the data set average, $0.0805 \alpha \mathrm{Ci} / \mathrm{g}$, compares well with total $\alpha$-activities calculated from other data and data set averages of Table 1, as well as from those samples with the highest or lowest percentage of each radionuclide. Only alpha-activities of unique samples (first encounter) are recorded in Table 3. A blank appears where otherwise a calculation of $\alpha$-activity would have been repeated. Note that, as expected from expression (2), the extreme high $\mathrm{Pu}-239$ isotopic fraction is from the sample with the extreme low $\mathrm{Pu}-240$ isotopic fraction (and vise versa).

Because a very accurately determined $\mathrm{Pu}-239$ content dominates the $\alpha$-activity calculation, scatter is quite small $(93 \%-112 \%$ of the average value, even at the extremes). Remarkably, the outlier also has a satisfactory $\alpha$-activity (85\% of the average value) well within the narrowest accuracy limits (75\%-125\%) allowed by the TRU waste QAPP. The Np-237 high extreme seems to be another outlier (see Figure 3a), but it also causes no problems. Np-237 was below the minimum detectable limit in several batches, so no activity has been calculated for $\mathrm{Np} 237$ at the low extreme. 
Table 3. Range of $\alpha$-Activities Due to Variation in Plutonium Compositions

\begin{tabular}{|c|c|c|c|c|c|c|}
\hline \multicolumn{7}{|c|}{ 1. $\alpha$-Activity in $\alpha$ Ci/gram for Data Sets of Table 1 and the Outlier } \\
\hline & \multirow{2}{*}{$\begin{array}{l}\text { Outlier } \\
\text { Omitted } \\
\text { Average } \\
\text { (Unwt'd) }\end{array}$} & \multirow{2}{*}{$\begin{array}{l}\text { Wt'd by } \\
\text { TRU Mass } \\
\text { Average } \\
\text { (Wt'd) }\end{array}$} & \multirow[b]{2}{*}{ HWM Data } & \multirow[b]{2}{*}{$\begin{array}{c}\text { PDP } \\
\text { Validation } \\
\text { Standard }\end{array}$} & \multirow[b]{2}{*}{$\begin{array}{c}\text { Analytical } \\
\text { Validation } \\
\text { Standard }\end{array}$} & \multirow[b]{2}{*}{$\begin{array}{c}\text { Outlier } \\
\text { (\#17) }\end{array}$} \\
\hline & & & & & & \\
\hline $\begin{array}{l}\alpha \text {-Activity, } \\
\alpha \mathrm{Ci} / \mathrm{g}\end{array}$ & 0.0805 & 0.0809 & 0.0812 & 0.0772 & 0.0781 & 0.0687 \\
\hline \multicolumn{7}{|c|}{ 2. $\alpha$-Activity in $\alpha \mathrm{Ci} /$ gram for Data Sets Containing the Extreme Weight Fraction Values } \\
\hline & \multicolumn{3}{|c|}{ Extreme High-Weight Fractions } & \multicolumn{3}{|c|}{ Extreme Low-Weight Fractions } \\
\hline Radionuclide & $\begin{array}{l}\text { Data Set } \\
\text { Number }\end{array}$ & $\begin{array}{c}\text { Weight } \\
\text { Fraction }\end{array}$ & $\begin{array}{l}\text { Calculated } \\
\alpha \text {-Activity }\end{array}$ & $\begin{array}{l}\text { Data Set } \\
\text { Number }\end{array}$ & $\begin{array}{l}\text { Weight } \\
\text { Fraction }\end{array}$ & $\begin{array}{l}\text { Calculated } \\
\alpha \text {-Activity }\end{array}$ \\
\hline Pu-238 & \#33 & 0.00020 & 0.0813 & $\# 37$ & 0.00008 & 0.0860 \\
\hline Pu-239 & $\# 9$ & 0.93971 & 0.0785 & $\# 14$ & 0.93172 & 0.0875 \\
\hline Pu-240 & $\# 14$ & 0.06233 & & $\# 9$ & 0.05699 & \\
\hline Pu-241 & \#33 & 0.00281 & & \# 34 & 0.00101 & 0.0856 \\
\hline Pu-242 & \#21 & 0.00048 & 0.0760 & \#30 & 0.00019 & 0.0756 \\
\hline Am-241 & \#26 & 0.00438 & 0.0898 & \#22 & 0.00052 & 0.0757 \\
\hline $\mathrm{Np}-237$ & \#33 & 0.00042 & & & & \\
\hline
\end{tabular}




\section{Conclusions}

Based on this data set, weapons grade $\mathrm{Pu}$ is a material of uniform consistency for the purposes of waste characterization. Figure 5 shows that no significant systematic change has taken place in the composition during the time period of this data set (May 1993 through January 1997). Dispersion is large relative to any content variation with analysis date. Trends in the data can be expressed as the change in isotopic fraction per day. For isotopes of interest, the change is as follows: Pu-239, -0.00000001/day; Pu-240, 0.00000017/day; Pu-241, 0.00000016/day, and Am-241, 0.00000005/day. Figure 5 best-fit lines are essentially flat; clearly, trends are totally insignificant relative to data scatter.

Furthermore, the composition historically assumed by HWM is satisfactory, although the average composition determined here may be somewhat superior. Given the consistent isotope ratios of weapons grade Pu batches, an acceptable characterization can be accomplished by quantitatively determining only one or two nuclides (perhaps just Pu-239, or Pu-239 and Am-241). Average composition data will provide the rest to a high degree of accuracy. Approximately half of the Superblock TRU waste drums contain waste contaminated only with weapons grade $\mathrm{Pu}$. This waste can be analyzed by the SGS using present methods and moved out of the Superblock. It is not necessary to wait for an upgrade that will allow quantitative determination of all radionuclides. In general, there is no reason to analyze weapons grade $\mathrm{Pu}$ waste for all nuclides. Only a mixture containing an unspecified ratio of TRU isotopes justifies such an analysis.

Critical to use of the SGS for determining $\alpha$-activity is the measurement of absolute weight of $\mathrm{Pu}-239$, of total $\mathrm{Pu}$, or of any other $\mathrm{Pu}$ isotope. As was noted in a February 1997 memo by Jeff Glosup (see Appendix III), the gamma spectrometer measures isotopic ratios very well; measuring weight or absolute concentration is another matter. A reference given in that memo (ANSI N15.22-1987, Plutonium-Bearing Solids-Calibration Techniques for Calorimetric Assay, American National Standards Institute, New York) provides particularly good instrumental methods and experimental details. It does not solve the weight-calibration problem when a specimen has the uniformity of a waste drum's contents. As with any spectrophotometer, to obtain good data, the SGS requires a homogeneous sample in a precisely defined sample volume. Unless equivalent calibration standards (that can be run under identical conditions) are available, only a relative concentration (or relative weight) results. Pu samples with the narrow composition range noted here are not an additional source of analysis error. With significant errors in determining absolute concentration of TRU nuclides using the SGS, small effects due to very slight batch-to-batch differences in the relative weights of weapons grade $\mathrm{Pu}$ isotopes become insignificant

Arguments stated here must not be applied to contaminated weapons grade $\mathrm{Pu}$ or to mixtures containing other ratios of TRU nuclides. An average 
consistency can only be assumed for weapons grade $\mathrm{Pu}$. Other mixtures of radionuclides will need full characterization by the SGS, unless generator knowledge of the input material is adequate. A useful application of the SGS would be to provide a check and an alarm for TRU waste mistakenly identified as having solely weapons grade $\mathrm{Pu}$. Samples having $>0.15 \% \mathrm{Pu}-238$, $>1 \% \mathrm{Am}-241$, or $>98.5 \% \mathrm{Pu}-239$ will generally have $\alpha$-activity outside the allowed range. While misrepresented samples are expected to be rare, a convenient method to detect such problems could prove extremely valuable. Analytical data used as a check on generator knowledge would not need to meet the rigid quality-assurance/quality-control standards required of analyses.

Alloys of weapons grade $\mathrm{Pu}$ with other metals (not TRU) are common to the data set evaluated (see Appendix I) and have no effect. Generators are asked to note the presence of elements that the SGS fails to detect or that it analyzes poorly (e.g., uranium - present in a few samples at about the $5 \%$ level). Material containing minor amounts of even such exotic, extraneous nontransuranic metals can be accepted as weapons grade Pu for our purposes. All conclusions stated here can be shown to apply to such alloys. Finally, the methodology applied here might be used equally well to show the uniformity of $\mathrm{Pu}-238$ in the Superblock or of fuel-grade Pu. Average compositions for these materials could be defined, documented, and used similarly. 


\section{Abbreviations and Acronyms}

B332 Building 332

HWM Hazardous Waste Management

QAPP quality assurance project plan

RMA radioactive-materials area

SGS segmented gamma scanner

TRU transuranic

WIPP waste-isolation pilot plant 
Figure 1. Pu-239 Data Distribution is Approximately Gaussian

a) All Midtaune's Samples of Weapons Grade Plutonium

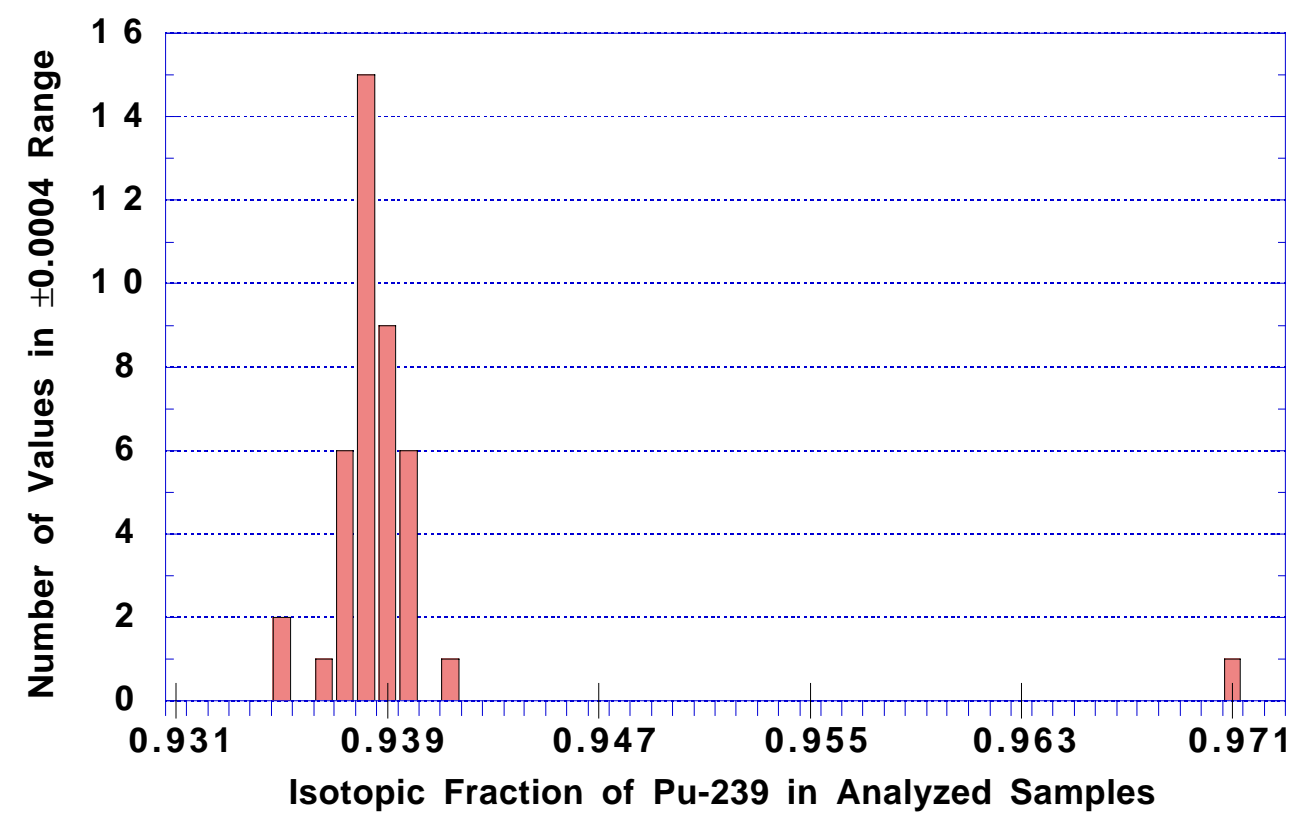

b) Midtaune's Samples of Weapons Grade Pu (Blowup; No Outlier)

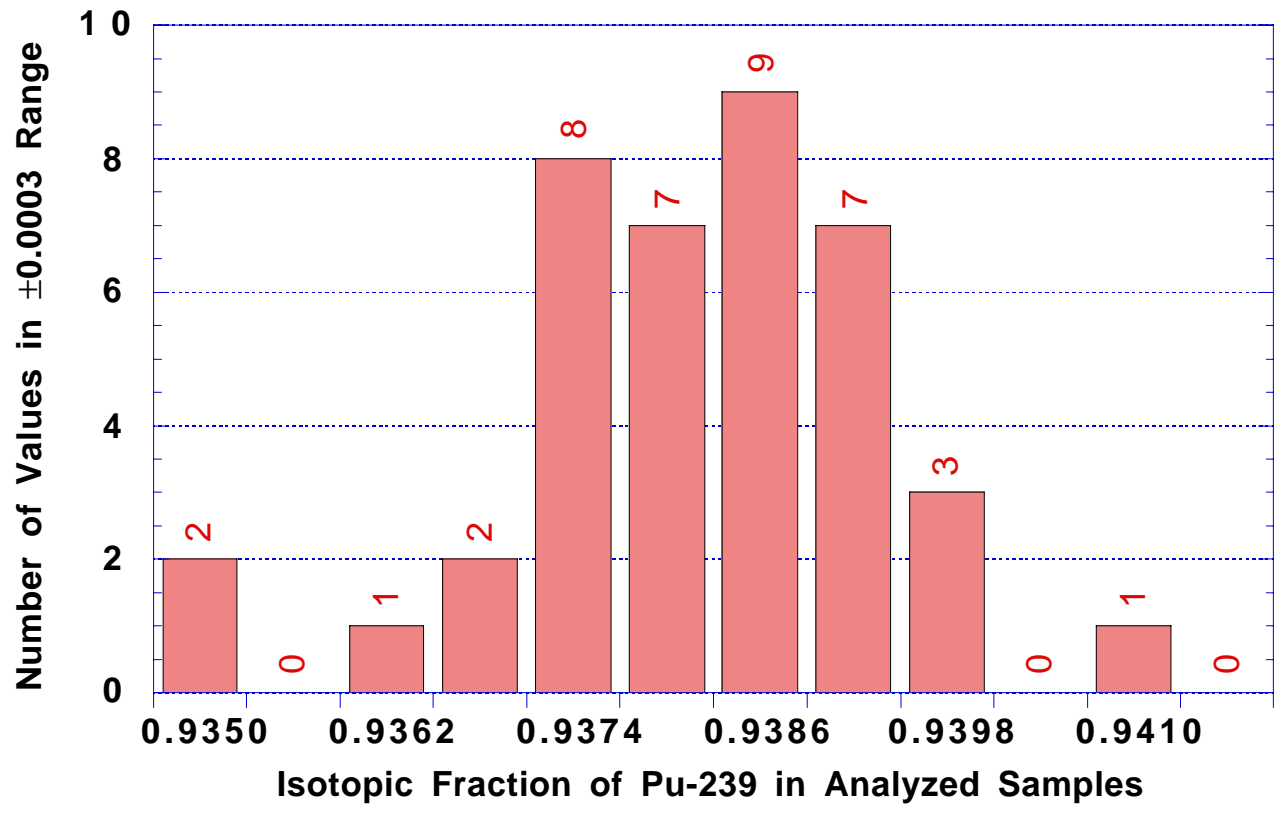


Figure 2. Daughter Contents Fail to Show a Strong Negative Correlation with Pu-241 Isotopic Fraction

a) Np-237 and Pu-241 Isotopic Contents Give a Poor Negative Correlation

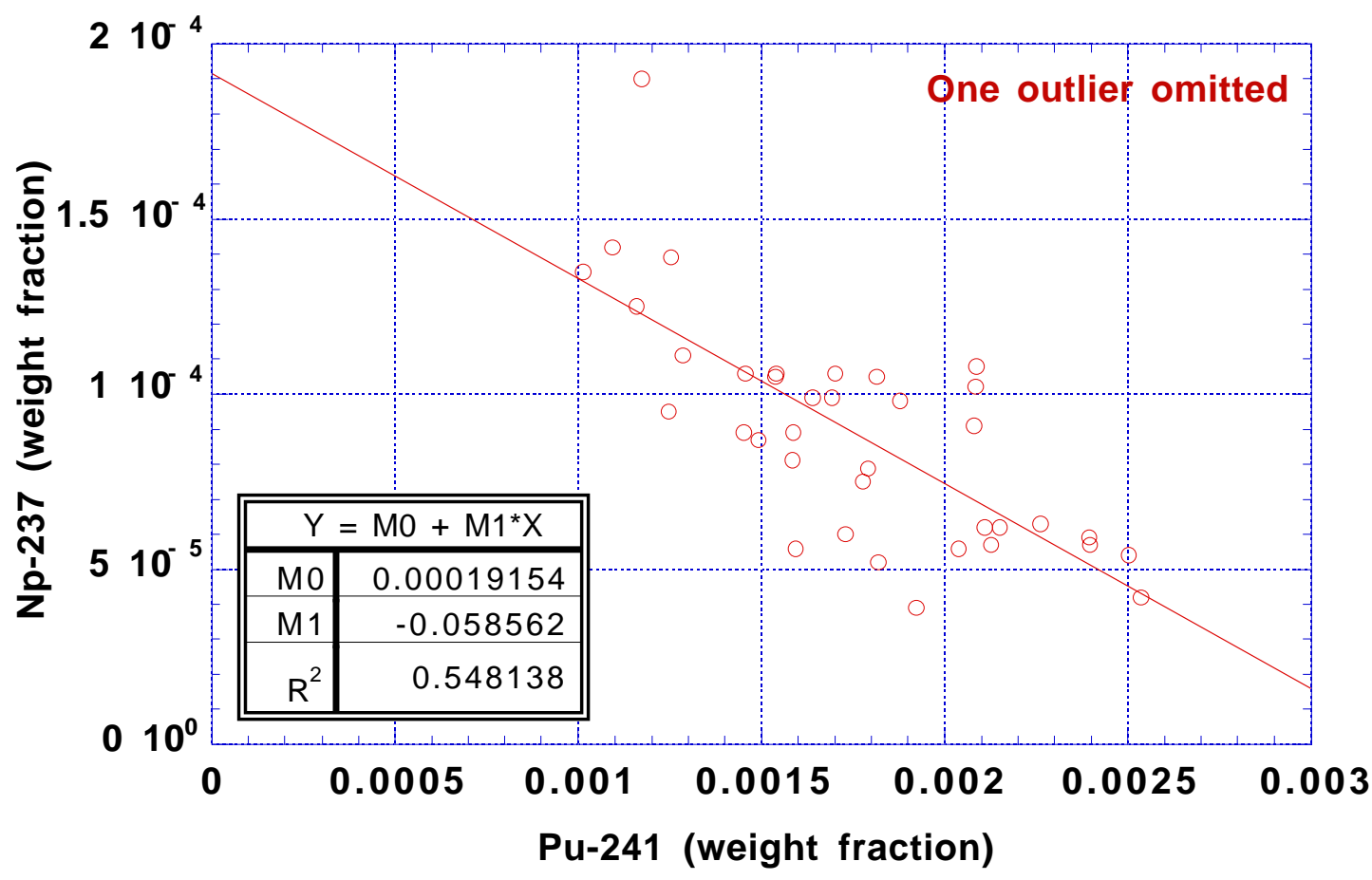

b) The Am-241 and Pu-241 Negative Correlation is Somewhat Poorer

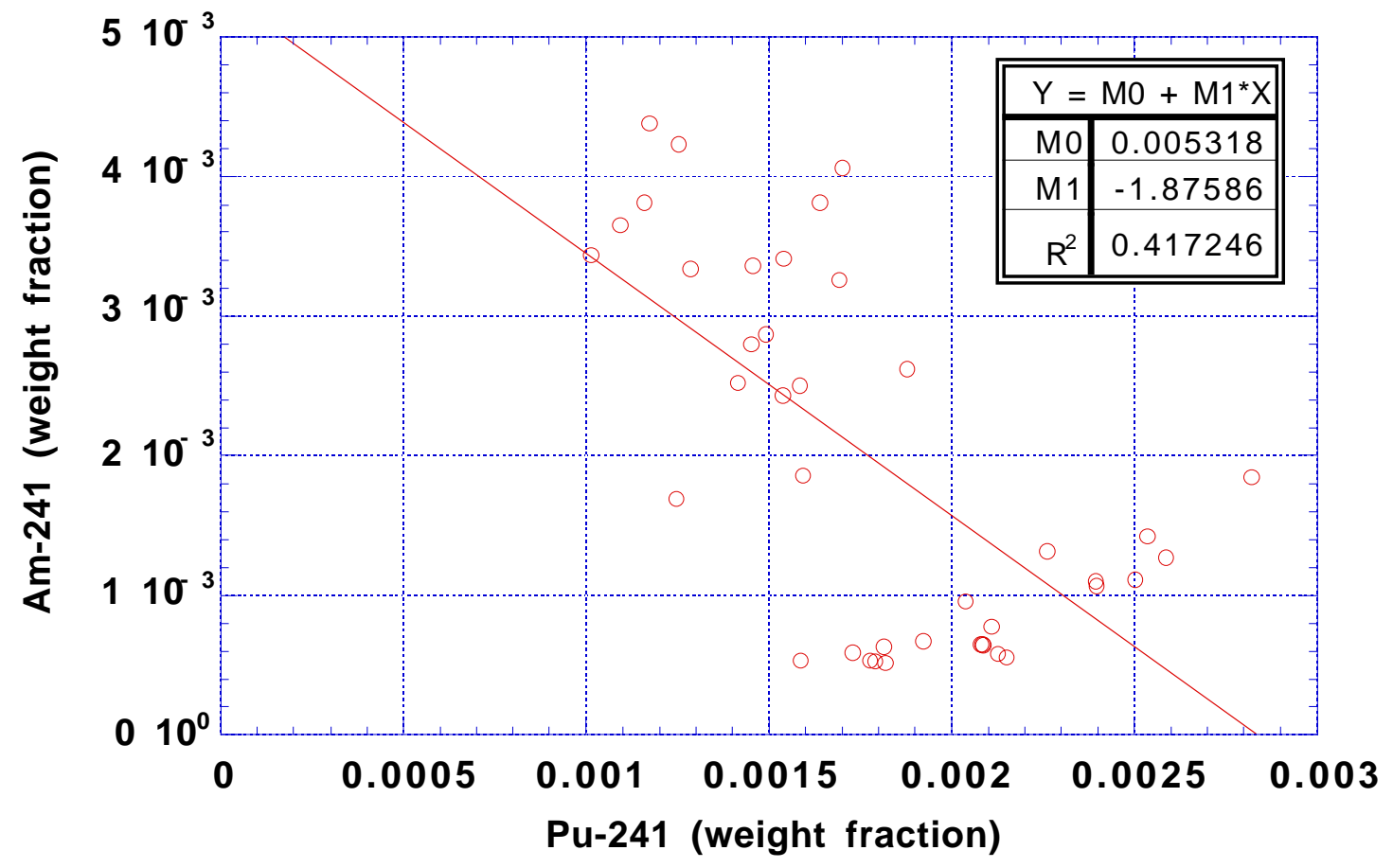


Figure 3. Pu-239, Pu-240, and Pu-242 Isotopic Fractions in Weapons Grade Pu

Are an Exponential Function of Mass

a) Raw Data Fits a Linear Exponential Function Defined by Average Data

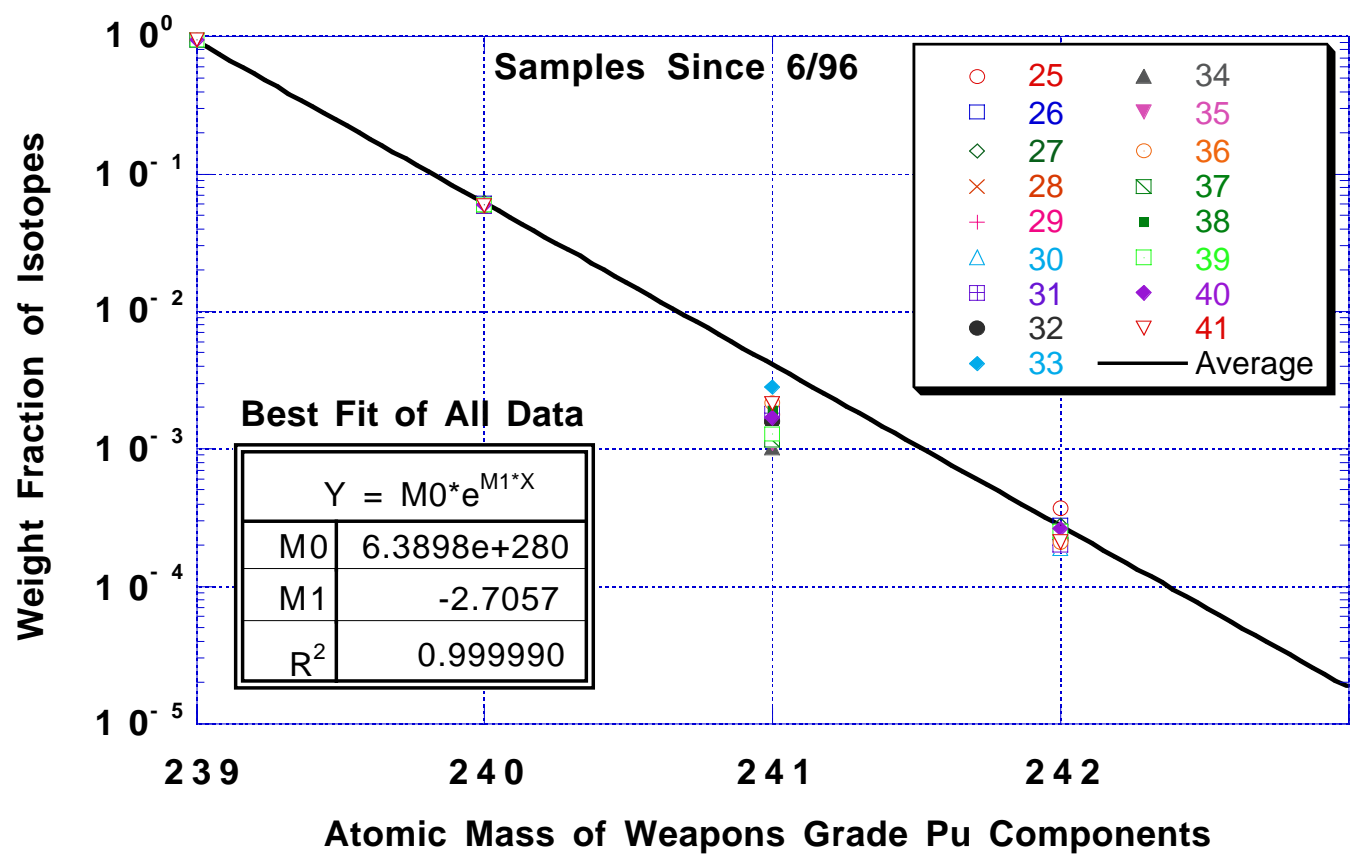

b) Outlier Isotopic Fractions Fall Off the Semi-Log Plot of Average Data

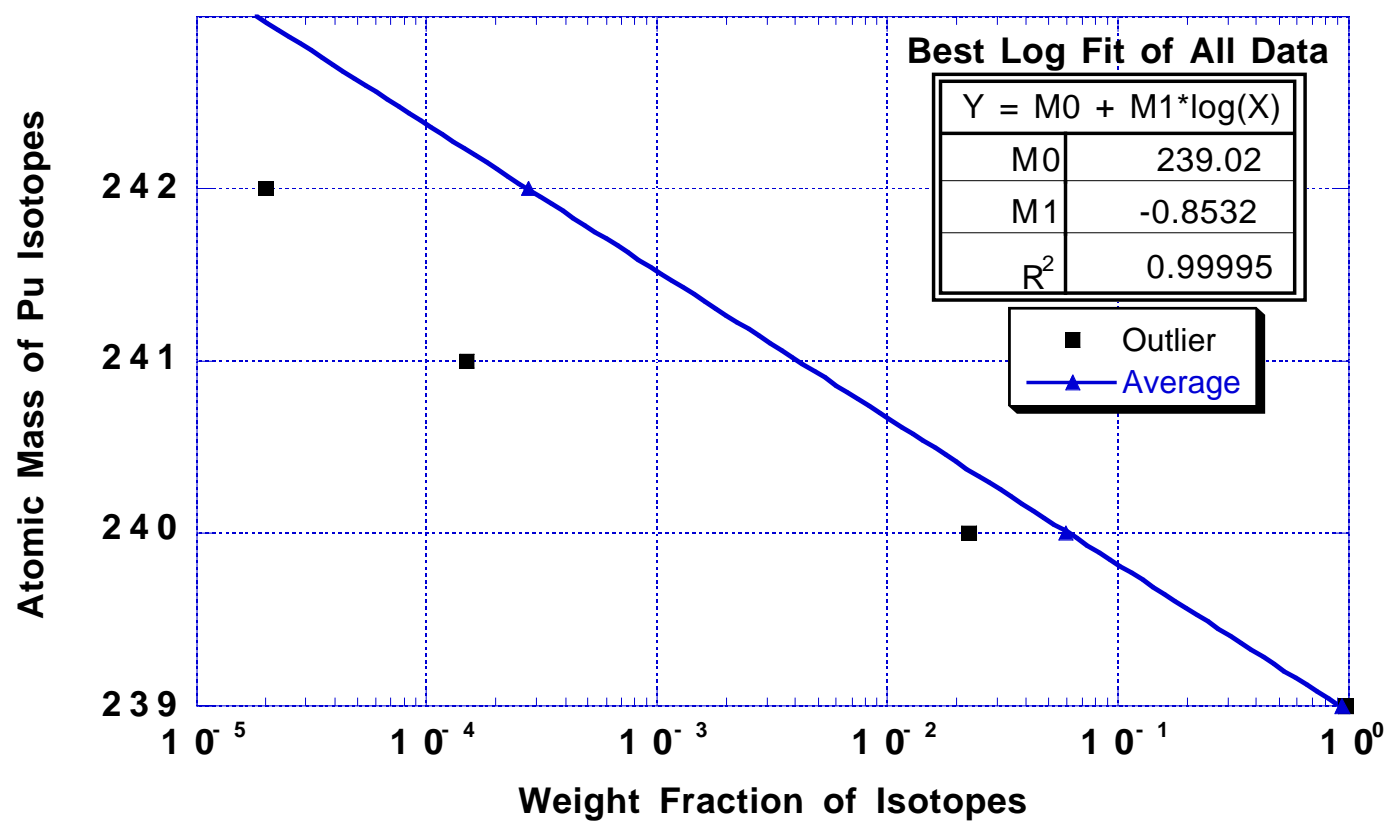


Figure 4. A Partial Knowledge of Plutonium Isotopes Allows an Estimate of Other Pu Isotopic Fractions

a) The Isotopic Fraction of Pu-240 and \{1- Fraction of Pu-239\} Correlate

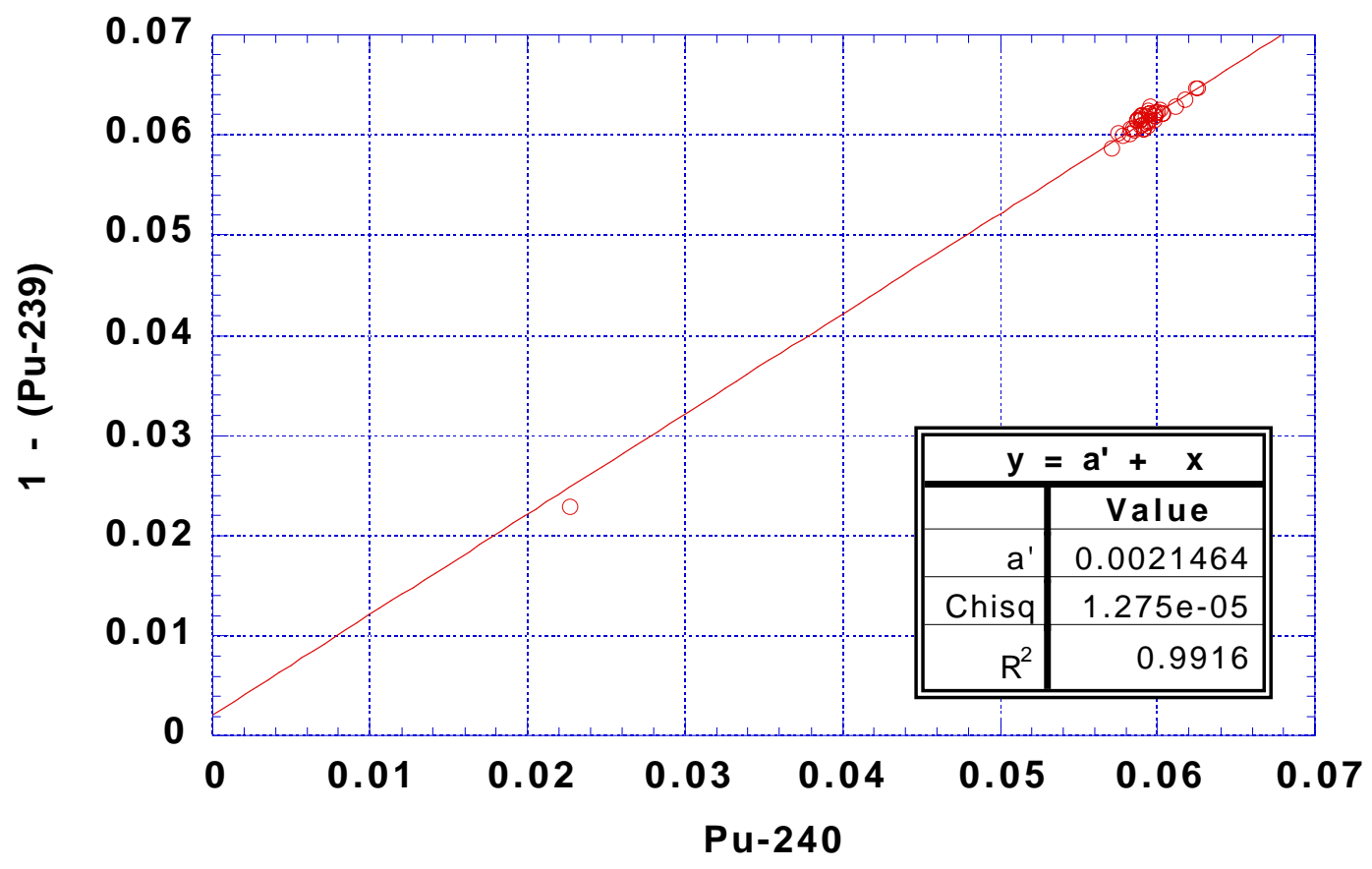

b) Pu-241 Content Correlates with \{1- Fraction of $(\mathrm{Pu}-239+240)\}$

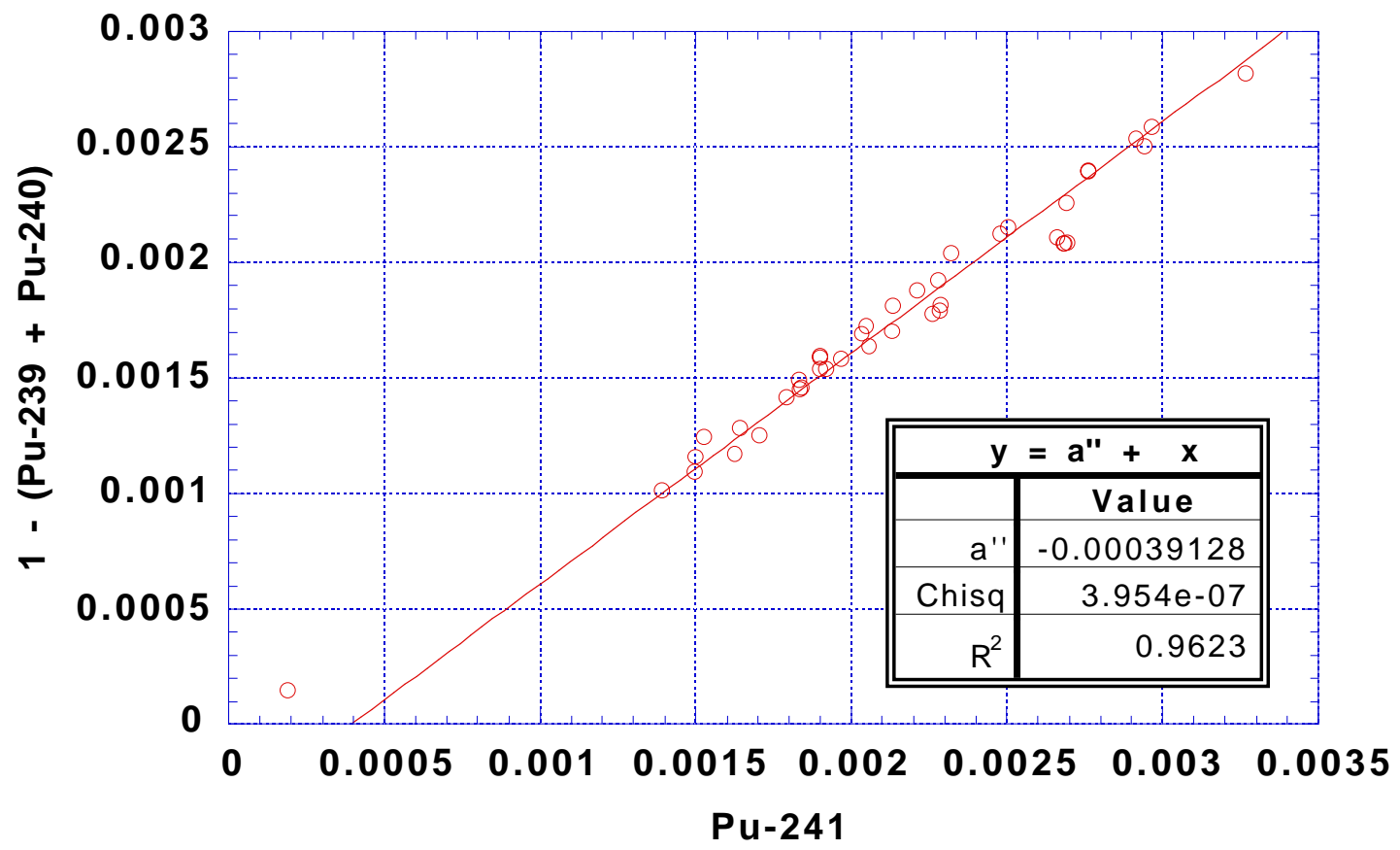


Figure 5. Weapons Grade Pu Composition Did Not Change During May 1993 through January 1997

a) The Significant Radionuclides Show No Systematic Changes Over Time

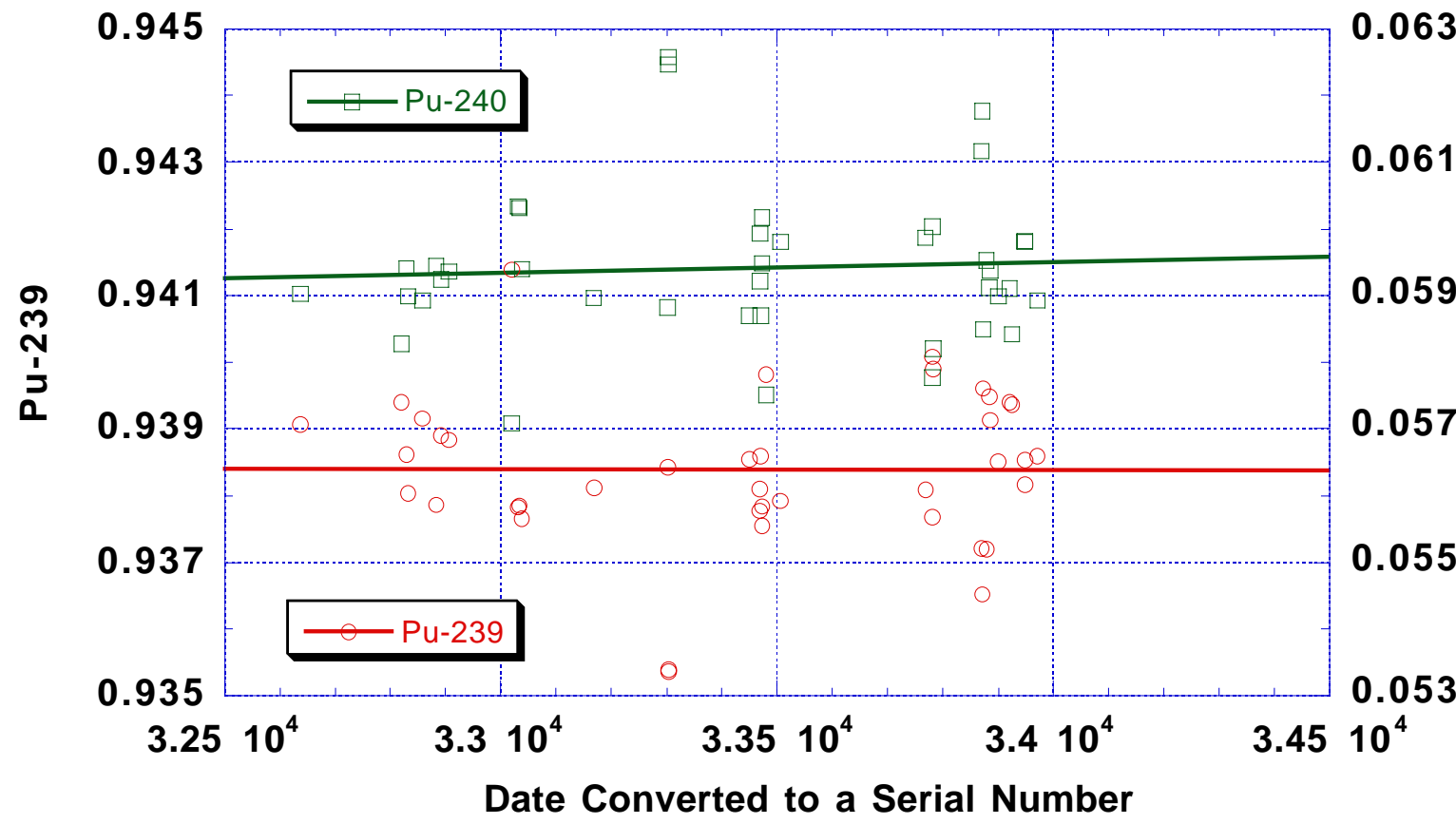

b) Variation in Pu-241 and Am-241 With Analysis Date Are Also Insignificant

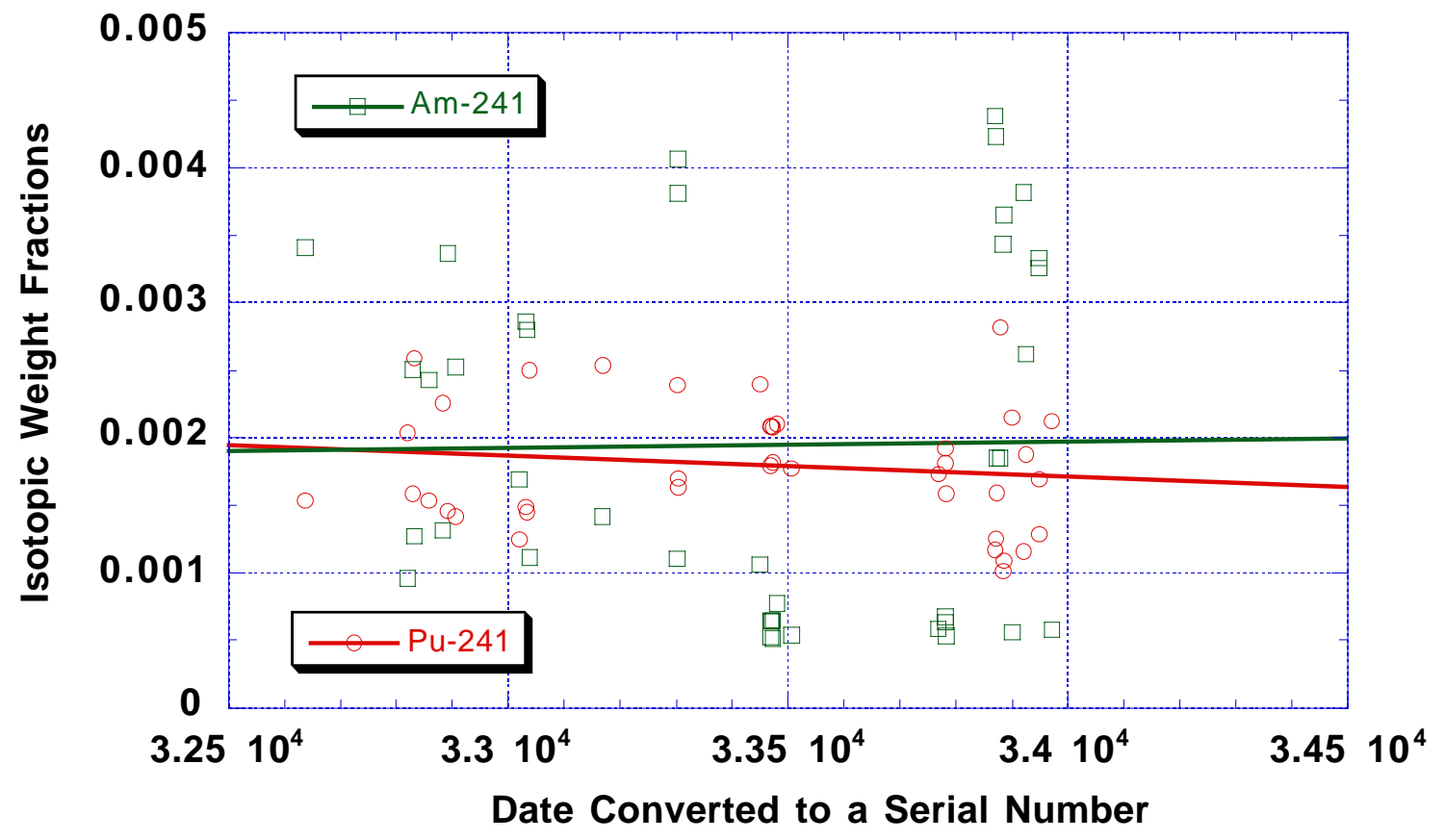


Appendix I

\section{Raw Data}




\section{Appendix I: Raw Data}

\section{Midtaune's Analytical Work on Weapons Grade Pu in the Superblock}

(Plutonium isotopes sum to 1 )

\begin{tabular}{|c|c|c|c|c|c|c|c|c|c|}
\hline Sample No. & 1 & $2(95 \%)$ & $3(82 \%)$ & $4(5 \%$ U) & 5 & 6 & 7 & 8 & 9 \\
\hline Anal. Date & $5 / 11 / 93$ & $11 / 9 / 93$ & $11 / 19 / 93$ & $11 / 22 / 93$ & $12 / 17 / 93$ & $1 / 11 / 94$ & $1 / 21 / 94$ & $2 / 3 / 94$ & $5 / 27 / 94$ \\
\hline Weight, $g$ & 2348.4 & 3328.9 & 2616.3 & 4907.9 & 3377.6 & 3762.7 & 3658.3 & 3394.2 & 3703.1 \\
\hline \multicolumn{10}{|l|}{ Analysis: } \\
\hline Pu-238 & 0.00010 & 0.00012 & 0.00009 & 0.00015 & 0.00009 & 0.00014 & 0.00009 & 0.00009 & 0.00008 \\
\hline Pu-239 & 0.93908 & 0.93940 & 0.93862 & 0.93804 & 0.93916 & 0.93787 & 0.93891 & 0.93884 & 0.94139 \\
\hline Pu-240 & 0.05903 & 0.05828 & 0.05941 & 0.05899 & 0.05892 & 0.05944 & 0.05925 & 0.05937 & 0.05709 \\
\hline Pu-241 & 0.00154 & 0.00204 & 0.00158 & 0.00259 & 0.00154 & 0.00226 & 0.00146 & 0.00142 & 0.00125 \\
\hline Pu-242 & 0.00025 & 0.00021 & 0.00029 & 0.00023 & 0.00029 & 0.00029 & 0.00029 & 0.00029 & 0.00020 \\
\hline Am-241 & 0.00341 & 0.00096 & 0.00250 & 0.00127 & 0.00243 & 0.00132 & 0.00336 & 0.00253 & 0.00169 \\
\hline $\mathrm{Np}-237$ & 0.00011 & 0.00006 & 0.00008 & 0.00000 & 0.00011 & 0.00006 & 0.00011 & 0.00000 & 0.00010 \\
\hline \multicolumn{10}{|c|}{ In the case of alloys, percent transuranic nuclides (or percent uranium) is indicated parenthetically next to the sample number } \\
\hline Sample No. & $10(82 \%)$ & $11(82 \%)$ & 12 & 13 & $14(63 \%)$ & $15(55 \%)$ & $16(63 \%)$ & 17 & $18(78 \%)$ \\
\hline Anal. Date & $6 / 9 / 94$ & $6 / 10 / 94$ & $6 / 15 / 94$ & $10 / 24 / 94$ & $3 / 7 / 95$ & $3 / 6 / 95$ & $3 / 8 / 95$ & $7 / 25 / 95$ & $8 / 1 / 95$ \\
\hline Weight, g & 1356.5 & 1353.6 & 3749.2 & 1982.2 & 1291.7 & 2081.8 & 1280.1 & 3625.7 & 3624.5 \\
\hline \multicolumn{10}{|l|}{ Analysis: } \\
\hline Pu-238 & 0.00009 & 0.00009 & 0.00015 & 0.00014 & 0.00014 & 0.00014 & 0.00015 & 0.00002 & 0.00014 \\
\hline Pu-239 & 0.93783 & 0.93786 & 0.93766 & 0.93812 & 0.93537 & 0.93842 & 0.93540 & 0.97711 & 0.93855 \\
\hline $\mathrm{Pu}-240$ & 0.06034 & 0.06031 & 0.05939 & 0.05897 & 0.06258 & 0.05882 & 0.06247 & 0.02270 & 0.05869 \\
\hline Pu-241 & 0.00149 & 0.00145 & 0.00250 & 0.00254 & 0.00164 & 0.00239 & 0.00170 & 0.00015 & 0.00240 \\
\hline Pu-242 & 0.00025 & 0.00029 & 0.00029 & 0.00023 & 0.00028 & 0.00022 & 0.00029 & 0.00002 & 0.00022 \\
\hline Am-241 & 0.00286 & 0.00280 & 0.00111 & 0.00142 & 0.00381 & 0.00110 & 0.00406 & 0.00072 & 0.00106 \\
\hline $\mathrm{Np}-237$ & 0.00009 & 0.00009 & 0.00005 & 0.00004 & 0.00010 & 0.00006 & 0.00011 & 0.00000 & 0.00006 \\
\hline \multicolumn{10}{|c|}{ Analysis Precision (as percent of value, $1 \sigma$ ): } \\
\hline Pu-238 & & & & $2.439 \%$ & $2.255 \%$ & $2.684 \%$ & $2.154 \%$ & $15.989 \%$ & $2.125 \%$ \\
\hline Pu-239 & & & & $0.511 \%$ & $0.511 \%$ & $0.515 \%$ & $0.509 \%$ & $0.122 \%$ & $0.510 \%$ \\
\hline $\mathrm{Pu}-240$ & & & & $0.678 \%$ & $0.642 \%$ & $0.697 \%$ & $0.640 \%$ & $1.047 \%$ & $0.636 \%$ \\
\hline $\mathrm{Pu}-241$ & & & & $0.597 \%$ & $0.614 \%$ & $0.602 \%$ & $0.597 \%$ & $2.192 \%$ & $0.564 \%$ \\
\hline Pu-242 & & & & $9.871 \%$ & $9.954 \%$ & $10.044 \%$ & $9.967 \%$ & $9.653 \%$ & $10.067 \%$ \\
\hline Am-241 & & & & $0.674 \%$ & $0.548 \%$ & $0.740 \%$ & $0.558 \%$ & $0.767 \%$ & $0.623 \%$ \\
\hline
\end{tabular}




\begin{tabular}{|c|c|c|c|c|c|c|c|c|c|}
\hline Sample No. & 19 & 20 & 21 & 22 & 23 & 24 & 25 & 26 & 27 \\
\hline Anal. Date & $8 / 21 / 95$ & $8 / 23 / 95$ & $8 / 22 / 95$ & $8 / 24 / 95$ & $8 / 31 / 95$ & $8 / 21 / 95$ & $9 / 26 / 95$ & $9 / 24 / 96$ & $9 / 25 / 96$ \\
\hline Weight, g & 2089.2 & 2216.6 & 2149.4 & 2190.4 & 2156.9 & 2172.5 & 2208.2 & 5131.2 & 5250.4 \\
\hline \multicolumn{10}{|l|}{ Analysis: } \\
\hline Pu-238 & 0.00012 & 0.00013 & 0.00013 & 0.00012 & 0.00014 & 0.00013 & 0.00011 & 0.00017 & 0.00017 \\
\hline Pu-239 & 0.93778 & 0.93783 & 0.93860 & 0.93754 & 0.93982 & 0.93810 & 0.93793 & 0.93721 & 0.93653 \\
\hline Pu-240 & 0.05994 & 0.05948 & 0.05870 & 0.06018 & 0.05752 & 0.05922 & 0.05981 & 0.06116 & 0.06176 \\
\hline Pu-241 & 0.00179 & 0.00208 & 0.00209 & 0.00182 & 0.00211 & 0.00208 & 0.00178 & 0.00117 & 0.00125 \\
\hline Pu-242 & 0.00037 & 0.00047 & 0.00048 & 0.00037 & 0.00041 & 0.00047 & 0.00037 & 0.00028 & 0.00028 \\
\hline Am-241 & 0.00053 & 0.00065 & 0.00064 & 0.00052 & 0.00078 & 0.00065 & 0.00054 & 0.00438 & 0.00423 \\
\hline $\mathrm{Np}-237$ & 0.00008 & 0.00009 & 0.00011 & 0.00005 & 0.00006 & 0.00010 & 0.00008 & 0.00019 & 0.00014 \\
\hline \multicolumn{10}{|c|}{ Analysis Precision $(1 \sigma)$ : } \\
\hline Pu-238 & $3.149 \%$ & $3.439 \%$ & $3.649 \%$ & $3.530 \%$ & $3.272 \%$ & & $3.607 \%$ & $5.335 \%$ & $2.445 \%$ \\
\hline Pu-239 & $0.255 \%$ & $0.574 \%$ & $0.584 \%$ & $0.521 \%$ & $0.574 \%$ & & $0.520 \%$ & $0.303 \%$ & $0.303 \%$ \\
\hline Pu-240 & $0.561 \%$ & $0.822 \%$ & $0.881 \%$ & $0.786 \%$ & $0.852 \%$ & & $0.749 \%$ & $0.698 \%$ & $0.689 \%$ \\
\hline Pu-241 & $0.481 \%$ & $0.737 \%$ & $0.758 \%$ & $0.703 \%$ & $0.748 \%$ & & $0.688 \%$ & $0.798 \%$ & $0.760 \%$ \\
\hline Pu-242 & $9.961 \%$ & $9.983 \%$ & $9.983 \%$ & $9.501 \%$ & $10.064 \%$ & & & $10.023 \%$ & $9.999 \%$ \\
\hline Am-241 & $0.811 \%$ & $0.970 \%$ & $1.010 \%$ & $1.058 \%$ & $0.895 \%$ & & $0.925 \%$ & $0.422 \%$ & $0.527 \%$ \\
\hline Sample No. & 28 & 29 & 30 & 31 & $32(5 \% \cup)$ & 33 & 34 & 35 & $36(87 \%)$ \\
\hline Anal. Date & $6 / 15 / 96$ & $6 / 28 / 96$ & $6 / 29 / 96$ & $6 / 27 / 96$ & 9/27/96 & $10 / 3 / 96$ & $10 / 8 / 96$ & $10 / 10 / 96$ & $10 / 25 / 96$ \\
\hline Weight, g & 2231.5 & 4383.8 & 4398.9 & 4394.1 & 4909.3 & 5923.3 & 5227.6 & 5186.9 & 1603.6 \\
\hline \multicolumn{10}{|l|}{ Analysis: } \\
\hline Pu-238 & 0.00012 & 0.00015 & 0.00012 & 0.00012 & 0.00009 & 0.00020 & 0.00013 & 0.00015 & 0.00015 \\
\hline Pu-239 & 0.93809 & 0.93769 & 0.93989 & 0.94009 & 0.93960 & 0.93721 & 0.93949 & 0.93913 & 0.93851 \\
\hline Pu-240 & 0.05986 & 0.06003 & 0.05821 & 0.05778 & 0.05850 & 0.05953 & 0.05912 & 0.05937 & 0.05899 \\
\hline Pu-241 & 0.00173 & 0.00192 & 0.00159 & 0.00182 & 0.00159 & 0.00282 & 0.00101 & 0.00109 & 0.00215 \\
\hline Pu-242 & 0.00020 & 0.00021 & 0.00019 & 0.00020 & 0.00022 & 0.00025 & 0.00024 & 0.00025 & 0.00021 \\
\hline Am-241 & 0.00059 & 0.00067 & 0.00053 & 0.00063 & 0.00185 & 0.00185 & 0.00343 & 0.00365 & 0.00056 \\
\hline Np-237 & 0.00006 & 0.00004 & 0.00009 & 0.00011 & 0.00006 & 0.00042 & 0.00014 & 0.00014 & 0.00006 \\
\hline \multicolumn{10}{|c|}{ Analysis Precision $(1 \sigma)$ : } \\
\hline Pu-238 & $2.322 \%$ & $2.895 \%$ & $3.119 \%$ & $2.607 \%$ & $2.842 \%$ & $1.541 \%$ & $3.502 \%$ & $2.900 \%$ & $2.978 \%$ \\
\hline Pu-239 & $0.508 \%$ & $0.147 \%$ & $0.134 \%$ & $0.107 \%$ & $0.083 \%$ & $0.104 \%$ & $0.136 \%$ & $0.134 \%$ & $0.517 \%$ \\
\hline Pu-240 & $0.623 \%$ & $0.587 \%$ & $0.555 \%$ & $0.451 \%$ & $0.349 \%$ & $0.403 \%$ & $0.575 \%$ & $0.556 \%$ & $0.740 \%$ \\
\hline Pu-241 & $0.596 \%$ & $0.487 \%$ & $0.473 \%$ & $0.364 \%$ & $0.307 \%$ & $0.287 \%$ & $0.716 \%$ & $0.635 \%$ & $0.637 \%$ \\
\hline Pu-242 & $10.083 \%$ & $9.994 \%$ & $10.050 \%$ & $10.013 \%$ & $10.000 \%$ & $9.994 \%$ & $9.963 \%$ & $10.025 \%$ & $10.096 \%$ \\
\hline Am-241 & $0.687 \%$ & $0.780 \%$ & $0.809 \%$ & $0.574 \%$ & $0.264 \%$ & $0.338 \%$ & $0.301 \%$ & $0.301 \%$ & $0.889 \%$ \\
\hline
\end{tabular}




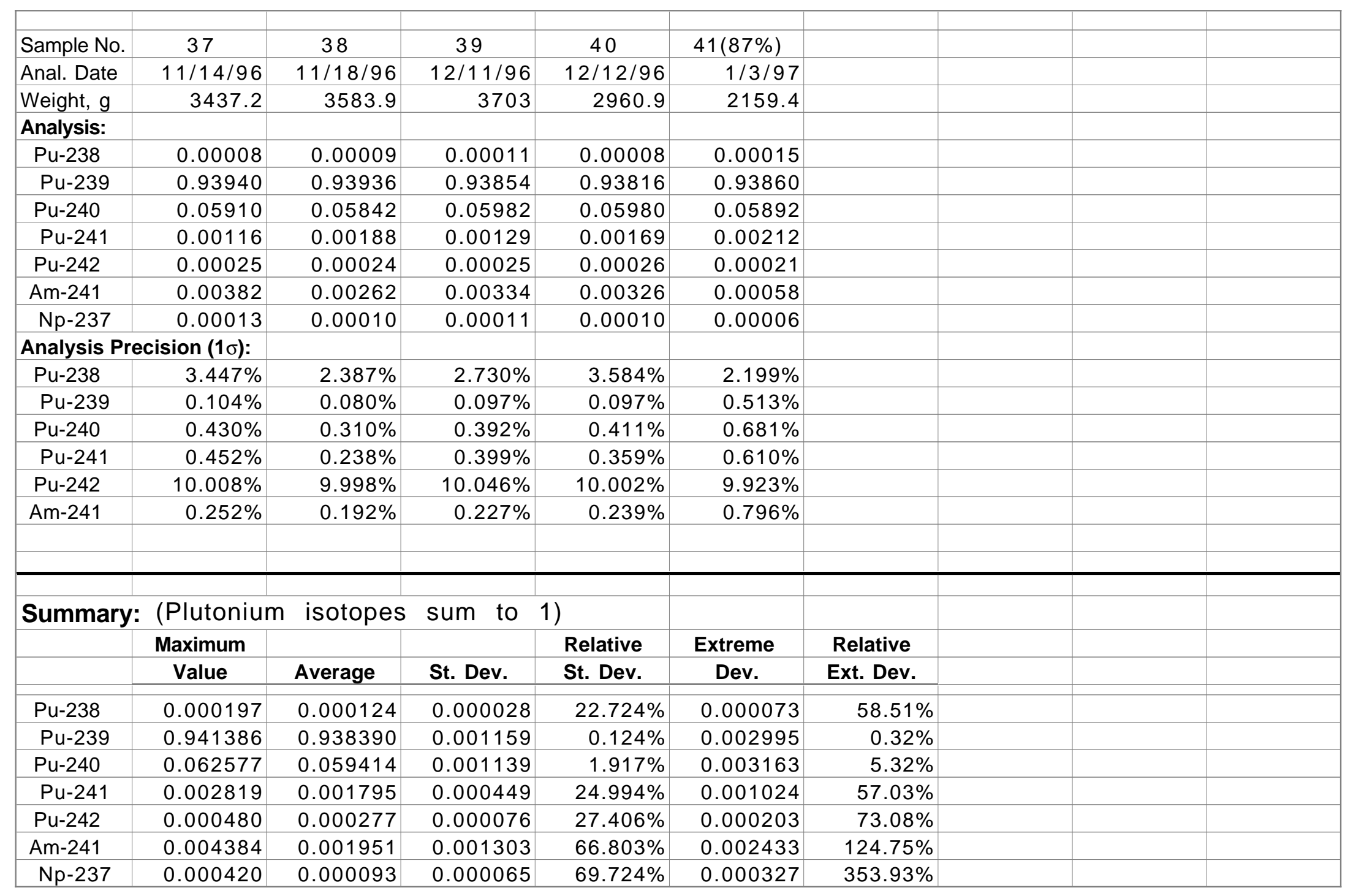




\section{Appendix II}

\section{An Example of the Calculation of Radiological Properties Using Standard Material and Properties, as Assumed by HWM}




\section{Appendix II}

\section{An Example of the Calculation of Radiological Properties Using Standard Material and Properties as Assumed by HMW}

\begin{tabular}{|c|c|c|c|c|c|c|c|}
\hline $\begin{array}{l}\text { Radio- } \\
\text { Nuclide }\end{array}$ & $\begin{array}{l}\text { HWM Comp. } \\
\text { Weight } \%\end{array}$ & $\begin{array}{l}\text { Sp. Activity } \\
\mathrm{Ci} / \mathrm{g} \text { isotope }\end{array}$ & $\begin{array}{l}\text { Alpha } \\
\text { Factor }\end{array}$ & $\begin{array}{c}\text { Activity } \\
\text { per gram TRU } \\
\text { Ci/g sample }\end{array}$ & $\begin{array}{c}\text { Alpha Activity } \\
\text { alpha-Ci } \\
\text { /g sample }\end{array}$ & $\begin{array}{l}\text { Sp. Thermal } \\
\text { Power }(W / g)\end{array}$ & $\begin{array}{l}\text { Thermal } \\
\text { Power } \\
\text { (W/g-Pu) }\end{array}$ \\
\hline Pu-238 & $0.016 \%$ & 17.11659 & $1.00 E+00$ & $2.739 \mathrm{E}-03$ & $2.739 \mathrm{E}-03$ & 0.573000 & $9.17 \mathrm{E}-05$ \\
\hline Pu-239 & $93.464 \%$ & 0.06214 & $1.00 \mathrm{E}+00$ & $5.808 \mathrm{E}-02$ & $5.808 \mathrm{E}-02$ & 0.001950 & $1.82 \mathrm{E}-03$ \\
\hline Pu-240 & $5.900 \%$ & 0.22782 & $1.00 E+00$ & $1.344 \mathrm{E}-02$ & $1.344 \mathrm{E}-02$ & 0.007160 & $4.22 \mathrm{E}-04$ \\
\hline Pu-241 & $0.381 \%$ & 102.99125 & $2.45 E-05$ & $3.924 \mathrm{E}-01$ & $9.614 \mathrm{E}-06$ & 0.003310 & 1.26E-05 \\
\hline Pu-242 & $0.040 \%$ & 0.00392 & $1.00 \mathrm{E}+00$ & $1.570 \mathrm{E}-06$ & $1.570 \mathrm{E}-06$ & 0.000117 & $4.68 \mathrm{E}-08$ \\
\hline Am-241 & $0.202 \%$ & 3.43145 & $1.00 \mathrm{E}+00$ & $6.932 \mathrm{E}-03$ & $6.932 \mathrm{E}-03$ & 0.116000 & $2.34 \mathrm{E}-04$ \\
\hline $\mathrm{Np}-237$ & & 0.00070 & $1.00 E+00$ & $0.000 \mathrm{E}+00$ & $0.000 E+00$ & 0.000021 & $0.00 E+00$ \\
\hline Total & $100.003 \%$ & & & $4.736 \mathrm{E}-01$ & $8.121 \mathrm{E}-02$ & & $2.58 \mathrm{E}-03$ \\
\hline
\end{tabular}




\section{Appendix III}

Letter re: Conversion of Measurement Data to Isotopic Data 
To: $\quad$ Chuck Parish

From: $\quad$ Jeff Glosup

Subject: $\quad$ Conversion of Measurement Data to Isotopic Data

CC: $\quad$ Bill Ruvalcaba, Todd Taylor

I understand that you need an algorithm for converting the measurement data we have from the calorimeters and the gamma isotopic scanners into data about all isotopes in an item. In this memo, I will explain what data we typically have from a calorimeter and from a gamma isotopic scanner, as well as the calculations that need to take place to get the grams of each isotope in the item. I will also describe the steps to calculate the element and isotope weight and enrichment for the item.

The calorimeter provides a single measurement for an item, the heat output in Watts (or milliWatts). I will denote this measurement by $W$. By contrast, the gamma isotopic measurement provides much more information about the item. Gamma isotopic analysis provides the composition of the item as a mass fraction of the isotopes of interest. The isotopes measured for Plutonium are ${ }^{238} \mathrm{Pu},{ }^{239} \mathrm{Pu},{ }^{240} \mathrm{Pu},{ }^{241} \mathrm{Pu}$ and ${ }^{241} \mathrm{Am}$. Additional information on the mass fraction of ${ }^{242} \mathrm{Pu}$ is also provided either through process knowledge or through a correlation analysis (details and references are provided in Gunnick (1990) ).

Let $f_{238}, f_{239}, f_{240}, f_{241}$, and $f_{242}$ denote the mass fractions of ${ }^{238} \mathrm{Pu},{ }^{239} \mathrm{Pu},{ }^{240} \mathrm{Pu},{ }^{241} \mathrm{Pu}$ and ${ }^{242} \mathrm{Pu}$ in the item with the constraint that $f_{238}+f_{239}+f_{240}+f_{241}+f_{242}=1$. Additionally let $f_{\mathrm{A}}$ denote the mass fraction of ${ }^{241} \mathrm{Am}$ in the item expressed as a ratio of ${ }^{241} \mathrm{Am}$ to total $\mathrm{Pu}$ content. The gamma isotopic analysis provides the values of $f_{238}, f_{239}, f_{240}, f_{241}, f_{242}$ and $f_{\mathrm{A}}$. Note that these values are only valid for a particular time because of radioactive decay and in growth of ${ }^{241} \mathrm{Am}$ and that if the gamma isotopic and calorimetric measurements are not made at essentially the same time, the isotope fractions must be decay corrected. 
Suppose the Plutonium isotopic mass fractions $f_{i}\left(t_{0}\right)$ (for $i=238,239,240,241$ and 242 )are measured at time $t_{0}$, and suppose the ${ }^{241} \mathrm{Am}$ mass fraction $f_{\mathrm{A}}\left(t_{\mathrm{A}}\right)$ is measured at time $t_{\mathrm{A}}$. Note that we allow for $t_{0} \neq t_{\mathrm{A}}$, although they are usually identical. The algorithm for decay correcting the $\mathrm{Pu}$ isotopic mass fractions to some later time $t$ (i.e. $t-t_{0}>0$ ) is

$$
f_{i}(t)=\frac{f_{i}\left(t_{0}\right) \exp \left[-\lambda_{i}\left(t-t_{0}\right)\right]}{F(t)}
$$

for $i=238,239,240,241,242$ where

$$
F(t)=\sum_{i=238}^{242} f_{i}\left(t_{0}\right) \exp \left[-\lambda_{i}\left(t-t_{0}\right)\right]
$$

and $\lambda_{i}$ is the decay constant for Pu isotope $i(i=238,239,240,241,242)$. The formula for correcting the ${ }^{241} \mathrm{Am}$ mass fraction is more complicated because the ${ }^{241} \mathrm{Pu}$ beta-decays into ${ }^{241} \mathrm{Am}$. Assuming the ${ }^{241} \mathrm{Am}$ mass fraction was obtained at time $t_{A}$, the formula for calculating ${ }^{241} \mathrm{Am}$ corrected mass fraction is

$$
\begin{aligned}
f_{A}(t)= & \frac{F\left(t_{A}\right)}{F(t)} f_{A}\left(t_{A}\right) \exp \left[-\lambda_{A}\left(t-t_{A}\right)\right] \\
& +\frac{K_{1} K_{2}}{F(t)} \frac{\lambda_{241} f_{241}\left(t_{0}\right)}{\lambda_{241}-\lambda_{A}} \exp \left[-\lambda_{241}\left(t_{A}-t_{0}\right)\right]\left\{\exp \left[-\lambda_{A}\left(t-t_{A}\right)\right]-\exp \left[-\lambda_{241}\left(t-t_{A}\right)\right]\right\}
\end{aligned}
$$

where $\lambda_{241}$ is the decay constant for ${ }^{241} \mathrm{Pu}, \lambda_{A}$ is the decay constant for ${ }^{241} \mathrm{Am}$, $K_{1}=0.9999754$ is the branching ratio for decay of ${ }^{241} \mathrm{Pu}$ to ${ }^{241} \mathrm{Am}, K_{2}=0.9999999$ is the ratio of atomic mass of ${ }^{241} \mathrm{Am}$ to the atomic mass of ${ }^{241} \mathrm{Pu}$, and $F(t), F\left(t_{A}\right)$ and $F\left(t_{0}\right)$ are as in equation (2). Further details on these decay corrections can be found in ANSI Standard N15.22-1987 (Plutonium-Bearing Solids - Calibration Techniques for Calorimetric Assay) or on pages 621-623 of Reilly (1991) .

The specific powers (measured in milliWatts/gram) for each of these isotopes are well-known physical constants. Let $S P_{238}, S P_{239}, S P_{240}, S P_{241}, S P_{242}$ and $S P_{\mathrm{A}}$ denote the specific powers of ${ }^{238} \mathrm{Pu},{ }^{239} \mathrm{Pu},{ }^{240} \mathrm{Pu},{ }^{241} \mathrm{Pu},{ }^{242} \mathrm{Pu}$ and ${ }^{241} \mathrm{Am}$ in milliWatts/gram. Then the total specific power of a particular item at time $t$ can be found as

$$
\begin{aligned}
S P_{\text {total }}(t) & =S P_{238} f_{238}(t)+S P_{239} f_{239}(t)+S P_{240} f_{240}(t)+S P_{241} f_{241}(t) \\
& +S P_{242} f_{242}(t)+S P_{A} f_{A}(t)
\end{aligned}
$$

The element weight of $\mathrm{Pu}$ in the item at a time $t$ can be calculated as the ratio of the power of the item as measured by calorimetry to the specific power of the item as calculated by 
equation (4) using the decay corrected isotopic fractions from the gamma isotopic counter. That is, the element weight $m_{\text {element }}$ is

$$
m_{\text {element }}=\frac{W}{S P_{\text {total }}(t)}
$$

where $W$ is the power of the item in milliWatts at time $t$, and the specific power has been decay corrected to the calorimetry date $t$. The resulting element weight is in grams.

The isotope weight of a weapons grade $\mathrm{Pu}$ item at a time $t$ is defined to be the mass of $\mathrm{Pu}$ isotopes ${ }^{239} \mathrm{Pu}$ and ${ }^{241} \mathrm{Pu}$ in the item. That is, the isotope weight $m_{\text {isotope }}$ is

$$
\begin{aligned}
m_{\text {isotope }} & =m_{\text {element }}\left[f_{239}(t)+f_{241}(t)\right] \\
& =\frac{W}{S P_{\text {total }}(t)}\left[f_{239}(t)+f_{241}(t)\right]
\end{aligned}
$$

where $t$ is the time of the calorimetry measurement and the weight is in units of grams. Likewise, the weight of any isotope of interest (in grams) can found by multiplying the element weight $m_{\text {element }}$ by the appropriate isotope fraction. Therefore the weights of ${ }^{238} \mathrm{Pu}$, ${ }^{239} \mathrm{Pu},{ }^{240} \mathrm{Pu},{ }^{241} \mathrm{Pu},{ }^{242} \mathrm{Pu}$, and ${ }^{241} \mathrm{Am}$ (in grams) are given by

$$
\begin{aligned}
& m_{238}=m_{\text {element }} \cdot f_{238}(t) \\
& m_{239}=m_{\text {element }} \cdot f_{239}(t) \\
& m_{240}=m_{\text {element }} \cdot f_{240}(t) \\
& m_{241}=m_{\text {element }} \cdot f_{241}(t) \\
& m_{242}=m_{\text {element }} \cdot f_{242}(t)
\end{aligned}
$$

and

$$
m_{A}=m_{\text {element }} \cdot f_{A}(t)
$$

respectively where $t$ is the time of the calorimetry measurement.

The enrichment of a weapons grade Pu item at a time $t$ is defined to be the percentage of ${ }^{240} \mathrm{Pu}$ in the item so the enrichment is simply enrichment $=100 f_{240}(t)$. The enrichment of items classified as primarily ${ }^{238} \mathrm{Pu}$ at time $t$ is defined to be the percentage of ${ }^{238} \mathrm{Pu}$ in the item and so enrichment $=100 f_{238}(t)$. Likewise, the enrichment of items classified as primarily ${ }^{242} \mathrm{Pu}$ at time $t$ is defined to be the percentage of ${ }^{242} \mathrm{Pu}$ in the item and so enrichment $=100 f_{242 .} .(t)$ 
I hope these formulae provide you with the information you need. If you have any questions, contact me at 3-0657

\section{References}

ANSI (1987). N15.22-1987 Plutonium-Bearing Solids-Calibration Techniques for Calorimetric Assay. New York, American National Standards Institute.

Gunnick, R. (1990). "MGA: A Gamma-Ray Spectrum Analysis Code for Determining Plutonium Isotopic Abundances, Volume 1: Methods and Algorithms." Lawrence Livermore National Laboratory, UCRL-LR-103220, Vol. 1, April 3, 1990.

Reilly, D., Ensslin, N., Smith, H. Jr., and Kreiner, S., Ed. (1991). Passive Nondestructive Assay of Nuclear Materials. Washington D.C., Office of Nuclear Regulatory Research. 